\title{
Strategi Pemasaran Rumah Sakit UMMI dalam Meningkatkan Pendapatan pada Masa Pandemi Covid-19
}

https://doi.org/10.25008/caraka.v2i2.61

Ajri Fathurrahman, Muhammad Isnaini

Universitas Budi Luhur - Jakarta

\begin{abstract}
The hospital is one of the companies that was originally a non-profit company engaged in helping the community to provide services, especially in the health sector. Competition among healthcare service providers is getting tougher, we can see from clinics, general hospitals, to special hospitals. In order to survive, hospitals must also be managed efficiently by producing excellent service so that they are able to provide satisfaction to all consumers who are the target of their marketing, therefore hospitals must have and implement efficient marketing programs. In this study, the researcher uses a constructivist paradigm where the researcher tries to construct the observations observed by the researcher.
\end{abstract}

Keywords: Covid-19, Hospital, Communication Strategy

\section{ABSTRAK}

Rumah sakit merupakan salah satu perusahaan yang awalnya merupakan perusahaan nonprofit yang bergerak dalam membantu masyarakat untuk memberikan pelayanan terutama dalam bidang kesehatan. Persaingan antarindustri penyedia layanan kesehatan semakin ketat, bisa kita lihat dari mulai klinik, rumah sakit umum, hingga rumah sakit khusus. Agar bisa bertahan, rumah sakit harus bisa dikelola secara efisien dengan menghasilkan pelayanan yang prima sehingga mampu memberikan kepusan kepada seluruh konsumen yang menjadi target dari pemasarannya. Oleh karena itu rumah sakit harus memiliki serta melaksanakan program pemasaran yang efisien. Pada penelitian ini peneliti menggunakan paradigma konstruktivis dimana peneliti mencoba untuk mengkonstruksi pengamatan-pengamatan yang diamati oleh peneliti.

Kata Kunci: Covid-19, rumah sakit, strategi komunikasi 


\section{PENDAHULUAN}

Virus Covid-19 mengakibatkan terjadinya perubahan pada tatanan kehidupan, baik dari segi ekonomi, politik, pendidikan, maupun sosial. Kenaikan jumlah orang yang terpapar virus semakin banyak sehingga berdampak kepada kehidupan sehari-hari. Merabaknya Covid-19 membuat orangorang enggan berobat ke rumah sakit, karena hawatir terjangkit virus itu, sehingga terjadi penurunan jumlah kunjungan pasien khususnya rawat jalan. Hal ini berdampak bagi pendapatan rumah sakit, terutama dari pasien umum dengan pembayaran pribadi, jaminan perusahaan, dan asuransi.

Rumah Sakit UMMI merupakan salah satu rumah sakit swasta di Kota Bogor yang menjadi salah satu rumah sakit rujukan pasien Covid-19. Status itu membuat angka kunjungan pasien pada tahun 2020 bulan april mengalami penurunan drastis. Kondisi itu memengaruhi nilai pendapatan rumah sakit yang biasanya di atas 80\%, kini menurun hingga 56\% (Annual Report Marketing, 2020).

Untuk mengatasi masalaah itu, rumah sakit melakukan sejumlah langkah agar pasien tetap mau berobat ke rumah sakit meski pandemi masih mewabah. Rumah sakit mengedukasi masyarakat dan perusahaan yang memiliki penjaminan asuransi, dan menyampaikan RS UMMI meskipun menjadi salah satu rumah sakit rujukan Covid-19, namun tetap aman untuk dikunjungi. RS UMMI memanfaatkan media sosial seperti Facebook, Instagram, dan Youtube dalam menyampaikan pesan-pesan tersebut.

Selain itu rumah sakit mengadakan event daring melalui zoom, dan google meet sebagai sarana penunjang mengedukasi masyarakat. Pemanfaatan platfrom daring dimaksimalkan dengan menghadirkan dokter spesialis sebagai pembicara, serta dibuatnya alur pendaftaran online melalui whatsapp. Awalnya pasien jika ingin berobat harus mendaftar secara langsung ke bagian pendaftaran, namun kini melalui aplikasi. Hal ini bertujuan untuk mengurangi kerumunan massa antrian pendaftaran pada saat di rumah sakit.

Adanya perubahan tersebut penting bagi rumah sakit untuk membangun komunikasi yang efektif dalam memberikan edukasi kepada masyarakat, agar tidak ragu datang ke rumah sakit meski di tengah pandemi. Hal itu dilakukan karena rumah sakit harus tetap bertahan dan berkembang dan itu tergantung dari kemampuan dalam memberikan respon terhadap kebutuhan konsumen dengan menyediakan layanan berkualitas. Untuk mencapai itu diperlukan sinergitas yang tinggi dari semua elemen di rumah sakit saat memberikan pelayanan kepada pasien.

Untuk itu, rumah sakit harus mengetahui siapa yang menjadi target mereka dan dengan cara apa harus mengkomunikasikannya. Apabila salah dalam menentukan strategi, maka target yang ingin dituju tidak akan tercapai. Dengan menentukan strategi komunikasi yang terencana, maka jenis komunikasi pemasaran yang diterapkan seperti, periklanan, personal selling, sales promotions, public relations, dan direct marketing akan membawa dampak yang baik pada peningkatan pendapatan.

Strategi pemasaran yang tepat dalam bauran pemasaran akan sangat menentukan keberhasilan kegiatan pemasaran sehingga rumah sakit tidak hanya dapat bertahan, namun dapat berkembang menjadi lebih baik.

\section{KERANGKA TEORI}

Bauran komunikasi pemasaran biasanya dikaitkan dengan penyampaian suatu pesan dan pemakaian visual yang tepat sebagai syarat utama keberhasilan program promosi. Sementara itu untuk tahapan komunikasi dan strategi pesan, disusun berdasarkan pencapaian kesadaran atas eksistensi sebuah produk atau jasa (awareness), menumbuhkan sebuah keinginan untuk memiliki 
atau mendapatkan produk yang diinginkan (interest), sampai dengan mempertahankan loyalitas pelanggan terhadap produk tersebut.

Secara umum, tujuan dari komunikasi adalah untuk mencapai perubahan seperti yang diinginkan. Menurut Soemanagara (2006) ada empat tujuan komunikasi yaitu perubahan pengetahuan (knowledge change), perubahan sikap (attitude change), perubahan perilaku (behavior change) dan perubahan masyarakat (social change). Bauran pemasaran semakin berkembang terutama dalam bidang jasa, tidak hanya meliputi place, product, promotion, dan price (4P), namun juga dari segi people, place, process, dan physical evidence yang dikenal dengan istilah Bauran Pemasaran 7P.

Secara umum konsep 7P ini (product, price, place, dan physical evidence) digunakan untuk mengambil keputusan dalam pembuatan strategi komunikasi pemasaran, dan dijelaskan sebagai berikut:

Product (The service. Produk didapat oleh konsumen dalam bentuk manfaat, dan memenuhi apa yang dibutuhkan oleh seorang konsumen, serta dapat memberikan kepuasan dengan baik. Sebenarnya pelanggan/konsumen dalam hal ini pasien, tidak membeli barang atau jasa, namun membeli manfaat dari sesuatu yang ditawarkan kepada mereka.

Seperti halnya rumah sakit yang bergerak di bidang jasa pelayanan kesehatan kepada pasien. Mereka datang berobat ke rumah sakit untuk membeli manfaat dari penawaran rumah sakit, mulai dari mulai fasilitas, pelayanan prima, penanganan semasa perawatan baik rawat jalan maupun rawat inap sehingga memunculkan rasa puas dan nyaman bagi pasien.

Price (Harga). Penetapan harga merupakan hal yang penting. Biasanya perusahaan akan menentukannya dengan penuh pertimbangan karena penetapan harga akan mempengaruhi pendapatan perusahaan. Harga merupakan salah satu faktor utama penentu posisi dan harus diputuskan sesuai dengan target pasar. Oleh karena itu, dalam sebuah perusahaan ada tim yang ditugaskan untuk menentukan harga sebelum disampaikan kepada konsumen.

Place (Lokasi Usaha). Lokasi usaha juga menjadi salah satu yang harus dipertimbangkan dalam mengembangkan sebuah usaha. Lokasi yang strategis tentu memiliki peluang yang lebih besar dalam menjangkau konsumen, serta memberikan akses publik yang jauh lebih mudah sehingga dapat menguntungkan bagi perusahaan. Kemudahan mengakses area ke lokasi perusahaan terutama perusahaan penyedia layanan jasa kesehatan yang memerlukan akses cepat, saat terjadi keadaan gawat darurat, sangat berpengaruh dan berperan penting bagi perusahaan.

Promotion (Strategi Promosi). Promosi merupakan salah satu cara yang dilakukan oleh sebuah perusahaan dalam menarik perhatian konsumen. Biasanya proses aktivitas seperti ini dilakukan secara persuasif dengan memberikan tawaran yang menarik tentang produk/jasa, baik dilakukan secara langsung maupun melalui iklan promosi perusahaan.

People (Sumber Daya Manusia). People merupakan asset utama dari sebuah perusahaan terutama dalam industri jasa. Hal ini sangat diperlukan dari sisi perusahaan karena semakin baik sumber daya manusia yang dapat memberikan pelayanan akan menyebabkan konsumen merasa puas, sehingga kemampuan SDM yang baik menjadi hal paling mendasar baik bagi internal maupun ekternal perusahaan.

Process (Proses atau Aktivitas Bisnis). Pelayanan dari sebuah jasa ataupun kualitas produk sangatlah bergantung pada proses penyampaian perusahaan/instansi kepada konsumen. Untuk menjamin mutu layanan (quality assurance), seluruh operasional perusahaan harus dijalankan sesuai dengan sistem dan prosedur yang terstandarisasi oleh karyawan yang memiliki kompetensi, komitmen, dan loyal terhadap perusahaan tempat dimana ia bekerja dalam mencari nafkah. 
Physical Evidence (Bukti Fisik Perusahaan). Building merupakan bagian dari bukti fisik, karakteristik yang menjadi nilai tambah bagi konsumen terhadap perusahan jasa. Perhatian terhadap interior, perlengkapan bangunan, termasuk lighting system, dan tata letak ruang yang lapang sangat penting dan dapat mempengaruhi mood pengunung.

Menurut Kotler dan Amstong, bauran promosi, disebut dengan bauran pemasaran, adalah kombinasi strategi yang paling baik dari unsur-unsur promosi yang digunakan oleh perusahaan dalam mencapai tujuan. Unsur-unsur tersebut merupakan alat dari komunikator pemasaran, dalam hal ini adalah perusahaan dalam berkomunikasi dengan pelanggan.

Terdapat lima unsur yang membentuk komunikasi pemasaran, disebut bauran komunikasi pemasaran. Alat-alat komunikasi yang dapat digunakan perusahaan yaitu advertaising (periklanan), sales promotion (promosi penjualan), personal selling (penjualan personal), public relations (hubungan masyarakat), dan direct marketing (pemasaran langsung) (Kotler and Gray, 2012).

Advertaising merupakan bentuk presentasi nonpribadi, dan promosi ide, sebuah barang atau jasa dengan sponsor tertentu. Iklan dapat didefinisikan sebagai sebuah pengiriman pesan melalu media berbayar oleh si pemasan iklan. Iklan bisa membantu mencapai hampir semua target pasar. Selain itu iklan juga merupakan media sarana yang ampuh untuk membangun kesadaran konsumen terhadap produk yang dijual. Iklan berdampak pada kesadaran calon pasien untuk mengetahui posisi, lokasi, dan jasa produk yang ditawarkan oleh RS UMMI kepada calon pasien.

Iklan biasanya memiliki sifat yang persuasif sehingga dapat membujuk, membangun, dan menyakinkan siapa pun yang akan memanfaatkan produk yang ditawarkan baik berupa benda, maupun jasa pelayanan (Kotler and Gray). Tujuan utama dari iklan adalah membujuk dan mengingatkan. Selain bersifat persuasif, iklan harus bersifat informatif terutama saat memperkenalkan produk baru, atau memberikan positioning tertentu terhadap produk baru, sehingga menumbuhkan minat terhadap produk tersebut.

Proses iklan yang informatif dan persuasif sangat diperlukan terutama pada saat persaingan meningkat. Tujuannya adalah untuk membangun permintaan selektif. Dalam mencapai hal tersebut biasanya para pengiklan memanfaatkan berbagai jenis media baik media cetak, media elektronik, dan new media untuk mencapai target sasaran auidens yang diinginkan.

Sales Promotion adalah intensif jangka pendek untuk mendorong pembelian atau penjualan. Menurut Kennedy dan Soemanagara, Sales Promotion didefinisikan sebagai arahan langsung terhadap produk dan merupakan kekuatan penjualan. Penggunaan promosi penjualan bisa menimbulkan efek yang cukup besar pada persepsi tentang sebuah merek. Promosi penjualan juga dapat membantu perusahaan dalam mencapai target sasaran yang diinginkan. Juga dapat mendorong produk baru untuk dipasarkan, sehingga meningkatkan jumlah pembelian, pengguna manfaat layanan, dan membantu membangun loyalitas pelanggan terhadap produk atau jasa layanan.

Personal Seliing (penjualan personal) adalah presentasi pribadi oleh sebuah perusahaan dengan tujuan menghasilkan penjualan dan membangun hubungan antara perusahaan dan pelanggan. Penjualan personal ini merupakan salah satu improvisasi dari penjualan menggunakan komunikasi person to person. Biasanya dilakukan oleh sales di bawah naungan manajer marketing yang mempromosikan produk secara langsung pada sasaran yang diinginkan. RS UMMI memiliki tim marketing yang berada di bawah naungan Direktur Pemasaran dan Pengembangan Bisnis untuk memasarkan dan memperkenalkan RS UMMI kepada calon pengguna manfaat layanan kesehatan terutama untuk perusahaan-perusahaan besar.

Biasanya komunikasi penjualan personal bersifat dua arah, baik dengan tatap muka secara 
langsung, melalui pesawat telpon, melalui platfrom Google meet, Microsoft Team, maupun zoom. Penjualan personal dapat berfungsi sebagai jembatan antara perusahaan dengan calon pelanggannya. Penjualan personal mempelajari kebutuhan pelanggan dan bekerja dengan orangorang pemasaran dan non pemasaran di dalam perusahaan untuk menciptakan nilai pelanggan. Personal Selling merupakan alat yang paling efektif dalam membangun preferensi, keyakinan dan tindakan pembelian (Kotler and Gary 2012).

Direct marketing (pemasaran langsung) adalah hubungan langsung dengan individu yang ditargetkan secara cermat menggunakan surat, telepon, faks, surat elektronik, internet dan sarana dengan konsumen tertentu (Kotler dan Armstrong, 2008). Definisi direct marketing menurut Belch yang dikutip oleh Kennedy dan Soemananggara (2006) adalah: "direct marketing is a system of marketing by which organizations communicate directly with the target consumer to generate a response or transaction". Di sini terlihat, Blech dan Belch menggambarkan adanya hubungan yang dekat dengan sasaran dan memungkinkan terjadinya proses komunikasi yang bersifat dua arah.

\section{Strategi Komunikasi}

Strategi komunikasi merupakan salah satu bagian yang penting ketika perusahaan melakukan atau merancang suatu program yang akan dilakukan oleh perusahaan. Menurut Onong Uchjana (2005), strategi komunikasi merupakan paduan perencanaan komunikasi (communication planning) dengan manajemen komunikasi untuk mencapai tujuan yang ditetapkan. Agar komunikasi yang dilakukan berjalan lancar, diperlukan sebuah strategi dan membentuk perencanaan serta pelaksanaannya.

Keberhasilan tim pemasaran RS UMMI berawal dari adanya perencanaan untuk para pasien, juga membangun jaringan komunikasi kepada perusahan-perusahaan agar orang-orang yang menjadi pasien atau calon pasien tidak ragu dan khawatir terhadap virus yang sedang mewabah saat mereka berkunjung ke rumah sakit.

Strategi pemasaran memiliki fungsi: (1) menyebarluaskan pesan komunikasi yang bersifat informatif, persuasif, dan instruktif secara sistematis kepada sasaran untuk memperoleh hasil yang optimal. Dalam hal ini rumah sakit UMMI menyebar infromasi melalui elemen-elemen yang disampaikan sebelumnya yaitu informatif, persuasif, dan instruktif; (2) menjembatani "cultur gap", akibat kemudahan mengoperasionalkan media yang jika dibiarkan akan merusak nilai-nilai yang dibangun. Dalam hal ini rumah sakit UMMI bisa tetap menjaga nilai kepercayaan dari pasien ataupun calon pasien, sehingga nilai-nilai yang sudah dibangun oleh rumah sakit UMMI tetap terjaga.

Komponen-komponen yang harus diperhatikan pada saat menyusun strategi komunikasi, menurut Jalaludin Rahmat (2005) adalah: (1) komunikator, yang akan menyampaikan materi atau pesan harus memiliki kredibilitas, karena indikator yang paling penting dalam komunikator adalah kredibelitas yaitu menyangkut kepercayaan dan keahlian. Pesan-pesan yang disampaikan harus dapat diterima dengan baik, dan berjalan dengan lancar tanpa ada miss communications; (2) materi pesan yang disampaikan dengan cara tatap muka maupun menggunakan media. Pesan dalam proses komunikasi adalah sesuatu yang disampaikan oleh pengirim (komunikator) kepada penerima (komunikan). Komunikatornya adalah RS UMMI, komunikannya, pasien dan calon pasien RS UMMI.

\section{Platfrom Digital}

Seiring perkembangan dunia digital dan perkembangan teknologi yang semakin canggih, saat 
ini terjadi digitalisasi dalam semua aspek kehidupan manusia. Pemberlakuan social distancing, physical distancing, dan juga pembatasan sosial berskala besar (PSBB) yang diberlakukan oleh pemerintah memberikan dampak yang signifikan pada kehidupan sosial budaya, pendidikan, dan perekonimian.

Hampir semua aktivitas saat ini dilakukan secara online. Penggunaan platfrom digital pada masa pandemi seperti ini dimanfaatkan secara maksimal oleh organisasi/instansi dalam membangun komunikasi satu sama lain. Dalam proses pelaksanaannya tentu tidak terlepas dari penggunaan berbagai macam jenis paltfrom digital.

Jenis-jenis paltfrom digital yang biasany digunakan adalah Zoom, Youtube, Instagram, Microsoft teem, dan Google meet. Selain itu dalam pemanfaatan platfrom digital, ini diperlukan perangkat yang cukup memadai untuk menunjang proses yang baik pada saat menjalin komunikasi.

\section{METODOLOGI}

Penelitian ini menggunakan paradigma konstruktivis dengan mengkonstruksi pengamatan yang diamati oleh peneliti. Menurut Agus Salim (2006) secara ontologis, aliran ini menyatakan, realitas itu ada dalam bentuk bermacam-macam konstruksi mental. Berdasarkan pengalaman sosial, bersifat lokal spesifik dan tergantung pada orang yang melakukannya.

Pendekatan penelitian yang digunakan adalah menggunakan kualitatif, sebagai prosedur penelitian yang menghasilkan data deskriptif berupa kata-kata tertulis atau lisan dari orang-orang yang diamati. Pendekatan ini diarahkan pada latar belakang dan individu tersebut secara holistik (utuh). Peneliti menggunakan pendekatan kualitatif karena peneliti bertujuan untuk memahami fenomena lebih dalam serta dapat menjelaskannya secara lengkap.

Menurut Creswell dalam Burhan bungin (2011) pendekatan kualitatif adalah proses penelitian dan pemahaman yang berdasarkan pada metodologi yang menyelidiki suatu fenomena sosial dan masalah manusia. Pada pendekatan ini, peneliti membuat suatu gambaran kompleks, meneliti kata-kata, laporan terprinci dari pandangan responden dan melakukan studi pada situasi alami.

Penelitian kualitatif ini merupakan sebuah penelitian yang bersifat deskriptif yaitu mencoba menggambarkan hasil penelitian secara menyeluruh dari suatu gejala atau keadaan yang timbul dengan menggunakan kata-kata tertulis maupun lisan dari perilaku orang-orang yang diamati.

Peneliti menentukan key informan dan informan berdasarkan pertimbangan tertentu. Pertimbangan tertentu ini, misalnya orang tersebut dianggap paling tahu dan menguasai serta kompeten sehingga akan memudahkan penelitian yang dilakukan. Ruslan (2003) mengemukakan, key informan adalah orang utama yang diharapkan menjadi narasumber informasi atau informasi kunci dalam suatu penelitian. Subjek penelitian dalam penelitian ini adalah divisi marketing dari RS UMMI Bogor. Sedangkan objek penelitian yang akan diteliti dalam penelitian ini adalah RS UMMI itu sendiri.

\section{HASIL PENELITIAN}

Strategi komunikasi pemasaran yang diterapkan oleh RS UMMI sudah mengaplikasi beberapa poin yang ada pada teori bauran pemasaran terutama dalam promosi untuk meningkatkan pendapatan sales pada masa pandemic Covid-19, yaitu memanfaatkan media iklan, penjualan secara langsung yang dilakukan oleh tim marketing RS UMMI, serta memanfaatkan platfrom digital. Hal-hal ini dilakukan oleh tim RS UMMI dalam memasarkan dan mempormosikan dari setiap produknya.

Produk yang dimaksud adalah pelayanan kesehatan yang diberikan oleh RS UMMI selama 
masa pandemi, diantaranya pemasaran secara langsung ke perusahaan-perusahaan dengan memberikan penawaran pelayanan kesehatan, juga memberikan informasi kepada pasien maupun calon pasien bahwa RS UMMI itu aman untuk dikunjungi, dan pelayanan kesehatan pun masih dapat dilakukan secara langsung di rumah sakit tanpa perlu rasa hawatir yang berlebihan. Selain itu juga melakukan penawaran langsung ke perusahaan,serta memanfaatkan platfrom digital seperti zoom, google meet, dan youtube sebagai media sarana untuk penyembaran infromasi. Salah satunya adalah program "Health Talk - Webinar" yang semasa pademi ini dilakukan secara berkala dan gratis, dengan menghadikan dokter-dokter spesialis dari RS UMMI sebagai pembicara.

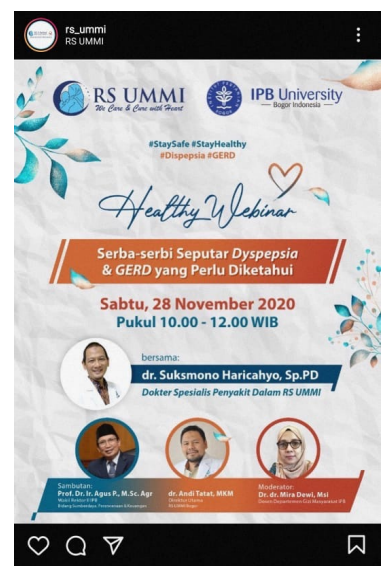

Gambar 1. Health Talk

Sumber: (https://www.instagram.com/rs ummi/?hl=id)

Untuk mempromosikan pelayanan kesehatan yang ada di RS UMMI, mereka membuat beberapa hal, diantaranya:

(1) Periklanan (advertaising). RS UMMI membuat iklan mengenai pelayanan kesehatan yang disuguhkan selama masa pandemic, menwarkan screening Covid-19, rapid antigen, maupun swab $P C R$ yang dapat langsung dilakukan perusahaan tanpa perlu datang kerumah sakit. Kegiatan iklan ini pun dilakukan oleh RS UMMI melalui media sosial yang dimilikinya seperti halaman facebook, Instagram, Twitter, dan brosur yang disebarluaskan secara langsung. Juga ada flayer digital dimana setiap karyawan aktif RS UMMI dianjurkan mengunggah ulang flayer digital tersebut di masingmasing media social mereka. Hal ini dinilai cukup baik karena mendapatkan hasil yang cepat serta feedback yang interaktif. Cara seperti ini dinilai cukup efektif tanpa mengeluarkan biaya berlebih terutama untuk iklan di media elektronik.

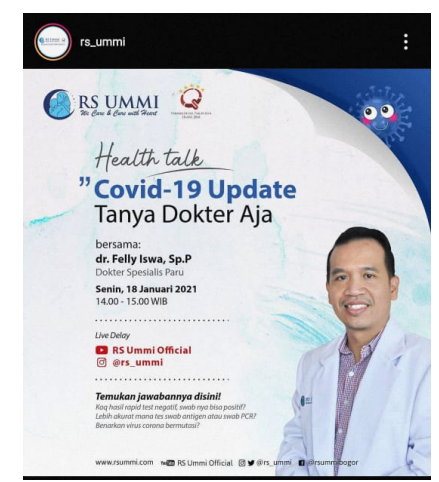

Gambar 2. Media Flayer Digital

Sumber: https://www.instagram.com/rs ummi/?hl=id

Strategi Pemasaran Rumah Sakit UMMI dalam Meningkatkan Pendapatan pada Masa Pandemi Covid-19 (Ajri Fathurrahman) 
(2) Penjualan perorangan (Personal Selling), dilakukan oleh RS UMMI dengan memaksimalkan media sosial dari karyawan aktif di rumah sakit. Direksi mengeluarkan internal memo yang mengarahkan karyawan untuk ikut berperan aktif dalam penyebaran infromasi terkait promo yang sedang berlangsung di rumah sakit. Selain itu rumah sakit juga bersinergi dengan relawan kesehatan, juga kader yang tersebar di wilayah Kota Bogor untuk menggiring pasien baik BPJS, umum, asuransi, dan juga jaminan perusahaan ke RS UMMI jika memerlukan pelayana kesehatan.

(3) Promosi penjualan (sales promotions). Promosi penjualan yang dilakukan oleh RS UMMI adalah dengan memberikan diskon untuk setiap pelayanan kesehatan terutama screening covid bagi perusahaan yang telah menjalin kerjasama dengan RS UMMI. Pada masa pandemi ini banyak sekali perusahaan yang memerlukan pelayanan screening covid. Tim marketing RS UMMI membaca hal ini sebagai peluang besar untuk bisa menjalin komunikasi kepada perusahaan-perusahaan dan akan mendapatkan previlage khusus apabila perusahaan/Instansi tersebut bekerjasama dengan rumah sakit dalam melakukan tindakan pelayanan Kesehatan. Proses ini dilakukan agar dapat menjangkau para pasien terutama pasien umum dengan jaminan perusahaan.

(4) Publisitas (public relation). Publisitas yang dilakukan oleh RS UMMI dengan membuat tulisan, baik di website milik rumah sakit, maupun dengan publisitas media cetak, juga media digital mengenai apa saja yang dilakukan oleh RS UMMI, serta promo apa saja yang ada di rumah sakit tersebut.

(5) Pemasaran langsung (direct marketing). Pemasaran langsung di RS UMMI melalu tim divisi pemasaran dan pengembangan bisnis. Mereka memberikan surat penawaran, langsung ke perusahaan-perusahaan yang memiliki potensi untuk meningkatkan pendapatan sales.

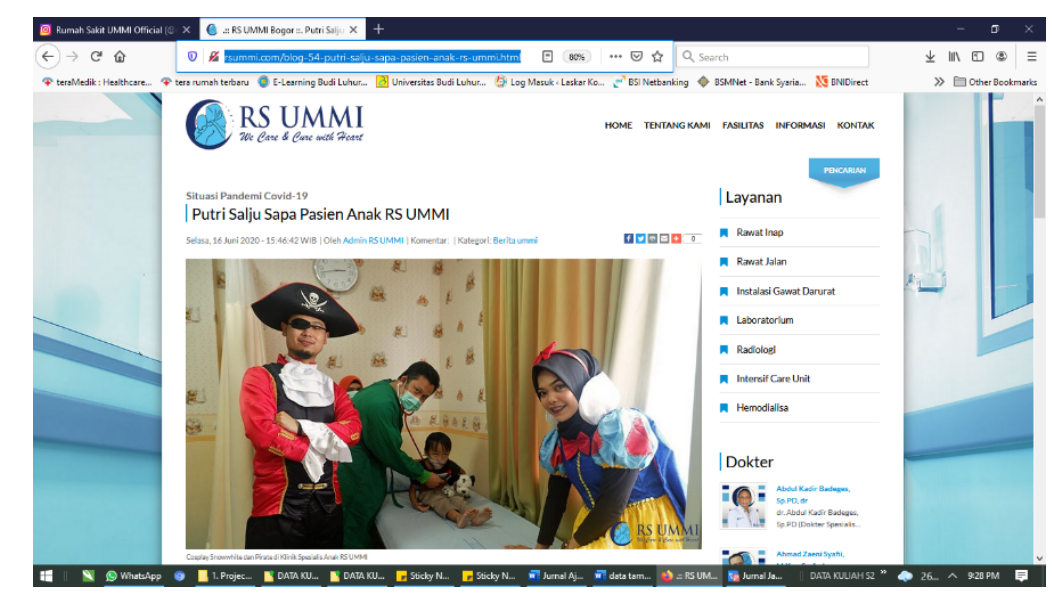

Gambar 3. contoh tampilan landing page web RS UMMI

Sumber: http://rsummi.com/blog-54-putri-salju-sapa-pasien-anak-rs-ummi.html

\section{KESIMPULAN}

Dengan adanya pandemi Covid-19, banyak orang yang enggan datang berobat langsung ke rumah sakit karena khawatir tertular virus Covid-19 sehingga menganggap rumah sakit tidak aman untuk dikunjungi. Hal ini mempengaruhi nilai pendapatan sales rumah sakit sehingga rumah sakit mengambil langkah-langkah perventif agar pendapatan mereka tidak terus menerus berkurang.

Selama pandemic Covid-19 banyak pembatasan pertemuan tatap muka secara langsung, maka rumah sakit beralih memanfaatkan platfrom digital sebagai media untuk menyampaikan pesan dari rumah sakit secara langsung kepada pasien, seperti pesan singkat melalu whatsapp, 
siaran langsung health talk di Intagran juga youtube.

\section{DAFTAR PUSTAKA}

Morissan. (2010). Periklanan komunikasi terpadu. Jakarta: Penerbit Kencana

Bungin, B. (2011). Pardigma dan Model Penelitian Komunikasi. Jakarta: PT. Raja Grafindo Persada

Bungin, B. (2013). Sosiologi Komunikasi Teori, Paradigma dan Diskursus Teknologi Komunikasi di Masyarakat. Jakarta: Kencana Prenada Media.

Jalaludin, R. (2005). Psikologi Komunikasi. Bandung: Remaja Rosda Karya.

Kartajaya, H. (2010). Konsep Pemasaran. Jakarta: Erlangga

Kotler, P., Kevin, L.K. (2019). Manajemen Pemasaran, Jakarta: Erlangga

Kotler, P., Gray, A. (2012). Prinsip-prinsip Pemasaran, Jakarta: Erlangga

Ruslan, R. (2003). Metode Penelitian Public Relations dan Komunikasi, Jakarta: PT. Raja Grafindo Persada

Salim, A. (2006). Teori Paradigma Penelitian Sosial. Jakarta: Kencana Prenada Media.

Hermawati, T dkk. Strategi Komunikasi Pemasaran Rumah Sakit Sebagai Upaya Peningkatan Publisitas. Universitas Sebelas Maret Surakarta.

Indisari, F dkk. Krisis Komunikasi Pada Masa Pandemi Covid-19 (studi kasus pemberitaan Penyebaran covid-19 melalui udara). Universitas Dehasen Bengkulu.

Ratnasari, A. (2008). Komunikasi Kesehatan: Penyebaran infromasi gaya hidup sehat. Mediator 9(1). 